\title{
Returning objects to Italy
}

\begin{abstract}
It is more than 20 years since the raids on the premises at the Geneva Freeport linked to Giacomo Medici. The seizure of photographic records led to a major investigation of acquisitions by museums and private collectors. This was expanded following the seizure of archives from Robin Symes and Gianfranco Becchina. Over 350 items have been returned to Italy from North American public and private collections, as well as auction houses and galleries. This paper reviews the returns and identifies some of the major themes. It also notes some of the unresolved cases both in North America but also Europe and Japan.
\end{abstract}


The last two decades have seen a major shift in attitudes towards 'looted' antiquities. Up to this point concerns had been raised, but there was rarely substantial and compelling proof that would persuade a museum to hand over its costly acquisitions. In 1997 Peter Watson exposed the scandal surrounding the selling of recently-surfaced antiquities through Sotheby's in London based on the release of documentary evidence released by an employee of the auction house, and this led to a decision by the auction house to stop selling 'ancient art' through its London premises. ${ }^{1}$ In 1995 raids on the Geneva Freeport premises linked to Giacomo Medici brought about the confiscation of large numbers of antiquities as well as a photographic archive of material handled by this individual. ${ }^{2}$ This seizure led directly to the return of material from North American collections. ${ }^{3}$

This study primarily provides an overview of the objects that have been returned to Italy from North American public museums, private collectors, and dealers. Secondly, it highlights some of the material that continues to be a matter of concern and that has been mentioned in earlier discussions. Thirdly, it discusses some of the information that has started to emerge from the returns about the routes by which objects moved from Italy to North America. Fourthly, it considers some of the broader categories of material.

\section{Public Collections}

North American museums had long been seen as acquirers of material derived from archaeological sites in Italy. In 1972 New York's Metropolitan Museum of Art (MMA) acquired the Attic red-figured calyx-krater that showed the death of Sarpedon before Troy ('Euphronios krater'). ${ }^{4}$ This was hailed as a major acquisition but soon attracted considerable attention. Philippe de Montebello, the director of the MMA had been a major critic of attempts by Italy and other countries to regain cultural property. ${ }^{5}$ In 1993 the museum agreed to return the so-called Lydian hoard of silver plate to Turkey that had been acquired over a number of years in the late 1960s. ${ }^{6}$ In February 2006 the museum announced that it would be returning the Sarpedon krater, as well as the 15 pieces of silver plate associated with the archaeological site of Morgantina in Sicily, an Attic amphora, and an Apulian dinos. In 2017 a Paestan krater attributed to Python was handed back after it had been identified from images in the Medici Dossier. ${ }^{7}$

In October of the same year Boston's Museum of Fine Arts (MFA) announced that it had come to an agreement with Italy. ${ }^{8} \mathrm{~A}$ year earlier it had rejected the concerns of Italy, but it quickly announced that it would be returning thirteen items ranging from a major portrait of Sabina, the consort of Hadrian, to Attic

\footnotetext{
${ }^{1}$ Watson 1997. See also Gill 1997. This decision has now been reversed and Sotheby's in London is once again auctioning antiquities.

2 Watson and Todeschini 2006.

${ }^{3}$ For an earlier overview: Gill 2009c; Gill 2010b.

${ }^{4}$ Gill 2012c. See Bothmer 1987.

${ }^{5}$ de Montebello 2007; de Montebello 2009.

6 Özgen and Öztürk 1996.

7 Tsirogiannis 2014.

8 Gill and Chippindale 2006.
} 
and South Italian pottery. Full collecting histories were provided for each of the returned objects and placed on the museum's website.

The J. Paul Getty Museum has made several returns to Italy. In 1999 it handed back the Euphronios / Onesimos cup, and in 2005 the Asteas krater, made in Paestum, as well as an Etruscan candelabrum and a Greek inscription. ${ }^{9}$ The museum made a major announcement timed to coincide with Thanksgiving Day 2006. ${ }^{10}$ A second statement covering additional material was issued in August 2007. The overall returns include the Morgantina statue of 'Aphrodite',11 painted marble sculptures from southern Italy, wall painting fragments from Campania, as well as Attic and South Italian pottery. Although the press release only listed the objects that were due to be returned, the museum staff helpfully supplied further details that made it possible to reconstruct part of the collecting histories. One of the other wall-painting fragments, formerly part of the Fleischman collection, was returned in 2009. A series of marble fragments acquired from Robin Symes in 1988 were returned in the spring of 2012. A further piece, a terracotta head of Hades, was handed over in 2013. The head's full collecting history appeared to have come to light as the museum prepared for a major loan exhibition on 'Sicily'.12 In 2017 a seated marble Zeus, formerly part of the Fleischman collection, was handed over to the Italian authorities after a fragment was identified from near Naples.

In 2007 two acrolithic sculptures on loan to the University of Virginia Museum in Charlottesville were returned to Sicily. They were clearly related to the 'Aphrodite' returned from the Getty. These acrolithic statues appear to have been looted from Morgantina around 1979, and were then handled by Robin Symes who sold them, in 1980, for Maurice Tempelsman for some \$1 million.

The Princeton University Art Museum came to an agreement with Italy in October 2007. Some material would be returned to Italy, but seven items retained in Princeton were legally transferred to Italy. The returned items included an Attic red-figured psykter that had featured in the Memoirs of Robert Hecht. Subsequent to this announcement, in December 2011 Princeton agreed to return a further batch of material to Italy including large numbers of Etruscan terracotta architectural fragments that had been acquired over several years. ${ }^{13}$ Some of the second group of objects were linked to the dealer Edoardo Almagià. They included the 157 Etruscan architectural fragments that had been presented to the museum in 1996. Part of the same series, a fragment given to the museum by the Aboutaam brothers of Switzerland, had been returned in the first batch of returns. The Ny Carlsberg in Copenhagen has returned some 500 antiquities to Italy including a large number of fragmentary Etruscan architectural terracottas. ${ }^{14}$

\footnotetext{
${ }^{9}$ Sgubini 1999; Watson and Todeschini 2006, 297; Felch and Frammolino 2011, 153-54, 267.

10 Gill and Chippindale 2007.

11 Felch and Frammolino 2011.

12 Lyons, et al. 2013, 192, fig. 133.

13 Gill 2012b.

14 Gill 2016a. For earlier discussion: Christiansen 2008. Many of the terracottas feature here: Christiansen, et al. 2010.
} 
The Cleveland Museum of Art agreed to return 14 objects in November 2008. The items included Apulian pottery, and silver Etruscan jewellery. Few details were provided about the collecting histories. However, it was possible to provide additional information, such as for the two Etruscan bracelets given to the museum by Almagià and Courtney Keep in honour of the former curator Arielle Kozloff. The majority of the Cleveland material included South Italian pottery, several the gift of Jonathan P. Rosen. A further returned piece was a marble portrait head of Drusus Minor that was acquired in 2012.15 This had been acquired with the suggestion that it had come from an old Algerian collection, but research by Italian academics demonstrated that it had been excavated at Sessa Aurunca in Italy and placed in an archaeological store.

The Minneapolis Institute of Art was a reluctant participant in the negotiations. There was a single disputed Attic red-figured krater that was identified from both the Medici dossier and the Schinousa archive. ${ }^{16}$ The public account was that it had formed part of private collections in England and Switzerland. The identification had been made public in November 2005 but the Institute had not opened negotiations with the Italian authorities. However, after the Director, Kaywin Feldman, issued a carelessly worded public statement in defence of the acquisition of an Egyptian mummy mask by the St Louis Art Museum, pressure was applied to the Institute to return the krater. ${ }^{17}$ This took place in 2012.

One of the earliest reports of potentially looted material in North American museums had included the mention of an Etruscan hydria attributed to the Michali painter in the Toledo Museum of Art. The museum agreed to return this in 2012, and it was handed over to Italian authorities in January 2013. The hydria had been acquired from Becchina in 1982.

One less well publicised transfer of ownership related to a Villanovan impasto hut acquired by the Fordham University Art Museum. ${ }^{18}$ This collection had been formed by William D. and Jane Walsh from the mid 1970s, and had been given by them to Fordham in 2006. Few of the pieces had collecting histories that could be traced back to the period before 1970 . The collection also includes Roman imperial bronzes that appear to belong to the Sebasteion at Bubon in Turkey.

The highly-publicised scandal relating to the Almagià material returned by Princeton to Italy prompted the Director of the Dallas Museum of Art, Maxwell Anderson, to identify material that came from the same source in his collection. ${ }^{19}$ This formed part of a voluntary return to Italy; in addition, a Roman mosaic was handed over to Turkey. Anderson has had a well-established and nuanced approach to the issue of recently surfaced antiquities. At Emory University he had established the Emory University Museum International Loan Project (EUMILOP) scheme that had encouraged the loans of major archaeological material from Italy such as one Roman funerary portraits, archaeological

\footnotetext{
15 Gill 2017.

16 Padgett 1983-86 [1991]; Gill 2011.

17 For the mask: Gill 2014a.

18 Cavaliere and Udell 2012.

19 Gill 2013a.
} 
material from Syracuse, and Roman coloured marbles. ${ }^{20}$ The unprompted investigation by Dallas appears to have allowed the objects to remain in the museum as loans from the Republic of Italy.

\section{Public Collections: unresolved cases}

Although significant returns have been made from public museums, additional archaeological material in other collections has been identified from the Polaroid images. While some of these acquisition habits can be traced back to the period before the 1970 UNESCO Convention, some of the more recently surfaced and disputed pieces are in North American collections. For example, the marble statue of a boy acquired by the Virginia Museum of Fine Arts in 1989 from Galerie Nefer appears to have featured in a transaction between Mario Bruno and Gianfranco Becchina in 1987.21 The same museum also has a Gnathian askos that it acquired in 1980 from Fritz Bürki. ${ }^{22}$ The Toledo Museum of Art has an Attic red-figured skyphos attributed to the Kleophon painter that has been identified in the Medici Dossier. ${ }^{23}$

There continue to be unresolved disputes with museums outside North America. The Miho Museum in Japan has often been cited in media reports and reportedly contains some 50 disputed objects. ${ }^{24}$ One of the objects that has been cited is a Roman marble oscillum. ${ }^{25}$ European museums have been notably absent from significant returns. The Italians took legal action against Leiden's Rijksmuseum van Oudheden for the return of a cuirass from Greek cavalry armour, acquired in 1998, but the Dutch courts rejected the claim in 2004. Some 15 objects acquired by the Allard Pierson Museum in Amsterdam had been handled by dealers and auction-houses such as Elie Borowski, Palladion Antike Kunst, Robin Symes and Sotheby's in London. The Museo Archaeológico Nacional in Madrid acquired the collection of Greek pottery formed by Várez Pisa. ${ }^{26}$ Some 22 pieces from this collection are reported to feature in the seized dossiers of photographs from Medici, Becchina and Symes.

All these examples suggest that the issue of acquiring recently surfaced archaeological material derived from Italy was not confined to museums in North America, but that it was a global phenomenon.

\section{Private collectors}

In 2000 classical material in private collections that had been placed in a series of public exhibitions in North America and Europe formed the basis of a major study. ${ }^{27}$ One of the striking things to emerge from the study was that a high

\footnotetext{
${ }^{20}$ Anderson and Nista 1988; Wescoat and Anderson 1989; Anderson and Nista 1989. For a discussion of the significance of EUMILOP: Butcher and Gill 1990. See also Anderson 2017.

21 Tsirogiannis 2013a.

22 Tsirogiannis $2013 \mathrm{~b}$.

23 Tsirogiannis 2017.

24 Miho Museum 1997.

25 Gill 2009d, 87.

${ }^{26}$ Cabrera Bonet 2003. See also Isman 2010.

27 Chippindale and Gill 2000. The methodology of the study has been revisited: Marlowe 2016; Gill 2016b.
} 
percentage of the objects had no stated collecting histories that could be traced back to the period before 1973 (the date of the adoption by the Archaeological Institute of America of their statement relating to illicit antiquities) and the 1970 UNESCO Convention. Two of the collections had been formed by Shelby White and Leon Levy and displayed at New York's Metropolitan Museum of Art as "Glories of the Past," and by Barbara and Laurence Fleischman in an exhibition displayed in the Getty and at Cleveland as "A Passion for Antiquities". ${ }^{28}$ The collection of George Ortiz had been displayed in the Royal Academy of the Arts in London as "In Pursuit of the Absolute".29

These collections had been formed no doubt by a genuine interest in the past. The exhibition titles indicate the way that these objects were viewed: "In Pursuit of the Absolute" suggests the hunter, the chase and the capture; the "A Passion for Antiquities" again evokes the idea of the search; and "Glories of the Past" suggests that these objects were the pinnacles of ancient art that have been received into this newly formed collection. This thinking behind this last title evokes the exhibition of the Hunt brothers, "Wealth of the Ancient World" suggesting that the objects within the show were somehow valued and valuable in antiquity. ${ }^{30}$ Such a position is clearly in tension with the ancient values. ${ }^{31}$

One of the issues that is overlooked by these collectors is that the real "treasures" and valuable objects have rarely survived from antiquity. Chryselephantine statues on the scale of Pheidias' mid-fifth century BC Olympian Zeus or Athena Parthenos have not survived the destruction of pagan temples in Late Antiquity. An exception would be the Roman ivory mask that was returned to Italy after being seized in London. ${ }^{32}$ Gold plate that features so prominently in temple inventories and classical texts rarely survives, though exceptions may include the Panagysusihte Treasure from Thrace, or the gold phiale returned to Italy from the collection of Michael Steinhardt. ${ }^{33}$ The same is also true for silver plate though some stunning examples have survived such as gold-figured silver plate from the burials at Duvanli, the royal burials at Vergina, or the Berthouville Treasure from northern France. Such material is largely absent from these private collections of "Wealth" and "Glories". Instead there is an emphasis on objects such as figure-decorated pottery made in Athens and Southern Italy. It is clear from ancient commercial trademarks scratched on the base of Athenian pottery that this category of ancient "art" was relatively cheap. ${ }^{34}$ For example an Attic red-figured pelike may be priced in obols, whereas a silver phiale could be worth 1 mina (the equivalent of 100 drachmas, or 600 obols) in bullion value alone. Yet Athenian and South Italian pottery has been privileged by the attribution of the pots to largely anonymous artists creating workshops, groups and spheres of influence. The implications of this research into ancient values

\footnotetext{
28 Bothmer 1990; Exhibition catalogue 1994.

${ }^{29}$ Ortiz 1994.

30 Tompkins 1983.

31 Vickers and Gill 1994.

32 Godart and De Caro 2007, 214-15, no. 60.

33 Lyons, et al. 2013, 44-46, fig. 24.

34 Vickers and Gill 1994.
} 
and the tension with the commercial value placed on modern collections of antiquities has been realised by those involved in the market. ${ }^{35}$

Research on these private collections has suggested that many of the objects did not have established and extensive collecting histories. Simon Mackenzie, a criminologist, has been critical of this approach suggesting that it would be inappropriate to suspect objects of being "looted" just on the grounds of an absence of full collecting history. ${ }^{36}$ However, the emergence of the Medici Dossier has identified objects from two of these private collections: Barbara and Lawrence Fleischman, and Leon Levy and Shelby White. A substantial number of the returns from the Getty included objects that had either been purchased or been received as a gift from the Fleischmans. Two of the items were fragments of a Roman wall-painting that seemed to come from the same composition as a fragment in the Shelby White and Leon Levy collection. One wonders how these fragments were separated as they passed through the market and ended up in separate collections. The Fleischman returns included Attic and South Italian pottery. However, the couple had also donated a Campanian bird askos to the Cleveland Museum of Art that has separately been returned to Italy. ${ }^{37}$

The Fleischman material was returned to Italy once it had been acquired by the Getty. However, Shelby White still retained the objects that had been formed with her husband. In January 2008 she finally came to an agreement with the Italian authorities to return 10 items, although the Kyknos krater attributed to Euphronios was not returned until $2010 .^{38}$ Two further objects were handed over to Greece in July 2008, and a disputed statue of the weary Herakles, which had also once formed part of their collection, was returned to Turkey from Boston. ${ }^{39}$ Several, though not all, of the items had appeared in "Glories of the Past". 40

These two prominent New York couples, with strong links to major North American public museums, feature prominently in the returns, but they are not the only North American collectors who owned material that has been returned to Italy. The Hunt Brothers had endeavoured to corner the world silver market but when their efforts were curtailed they were encouraged to turn their attention to antiquities under the guiding curatorial hand of some who perhaps hoped the collection would one day be passed to their museums. ${ }^{41}$ Due to financial difficulties the collection was dispersed and passed into other private collections. The Kyknos krater attributed to Euphronios passed into the Leon Levy and Shelby White collection, and the Etruscan antefix representing a satyr and a maenad entered the Fleischman collection, appearing on the cover of the catalogue of their collection: it subsequently formed part of the Getty's collection. The Athenian red-figured cup attributed to Euphronios had a complex history passing through the hands of Giacomo Medici and returning to Italy. ${ }^{42}$

\footnotetext{
35 Gill 2007.

36 Mackenzie 2005, 13-14.

37 Gill 2010b, 105, no. 9.

38 Exhibition catalogue 1990, 96-101, no. 6.

${ }^{39}$ Chi and Gaunt 2005.

40 Bothmer 1990.

41 Tompkins 1983.

42 Silver 2009.
} 
The Getty material also included a group of material that had been derived from the jeweller Maurice Tempelsman. ${ }^{43}$ The stunning painted marble griffins killing a doe had formed part of his collection: a picture from the Medici Dossier shows Medici posing in front of the group in the Getty. Other items from Tempelsman include a marble Apollo. He also owned the two acrolithic statues that were returned from Virginia to Sicily.

Another group of antiquities formed part of the Kluge collection, owned by financier John Kluge and Patricia Kluge. Returned material include bronze figures of an athlete and a nike, both stolen from museums in Italy, an Attic black-figured krater attributed to the Bucci painter, an Attic lekythos attributed to the group of Palermo 16, and a Paestan lekythos acquired from a Swiss private collection. In addition nine former pieces from the Kluge collection are reported to be in Madrid and form part of the Italian investigation.

Dietrich von Bothmer had curated the Greek and Roman collection at the Metropolitan Museum of Art. He was well known as a collector of pottery fragments, and some had featured in the returns from the Getty Museum, notably the red-figured krater attributed to the Berlin painter, and the Onesmimos cup. It is reported that Bothmer donated over 100 such fragments to the Getty although their collecting histories remain unclear. In January 2012 a carefully worded notice that omitted to name the owner announced that 40 fragments had been returned to Italy. ${ }^{44}$ It appeared that some of them fitted pots that had already been returned to Italy such as the Onesimos cup returned from the Getty. The Italian press subsequently revealed that they had belonged to Bothmer. The MMA eventually published a token number of images on the AAMD Object Registry, and one image showed the fragments for an Attic red-figured cup that was in the Villa Giulia in Rome. ${ }^{45}$ These specific fragments have now been returned.

Another collector of pottery fragments was Robert Guy, one-time curator at Princeton. He donated fragments for the Attic amphora attributed to the Berlin painter that was acquired by the MMA and returned to Italy alongside the Sarpedon krater. Yet the photographs from the Medici dossier indicate that the amphora passed through Medici. It remains unclear how fragments of it came into Guy's possession. Guy himself was the source of the large group of pottery fragments that were purchased by Harvard University Art Museum. ${ }^{46}$ This collection of pot sherds was defended by James Cuno, a former director at Harvard, who considered them to be insignificant. ${ }^{47}$ Yet it is now clear from both raids in Rome and a study of the returned finds, that near complete pots could be broken up as they passed through the market, and the pot restored by the final destination museum.

Among the private collectors represented in the returns was Jonathan Rosen. Five of the Cleveland objects had been donations by him. He had also contributed to the purchase of the Attic red-figured psykter that had been acquired by Princeton. He was also closely associated with the loan exhibition of Italian

\footnotetext{
43 Gill and Chippindale 2007.

44 Gill 2012a.

45 Tsirogiannis and Gill 2014.

46 Paul 1997.

47 Cuno 2008, 22-23.
} 
material in private collections that was displayed in Switzerland. ${ }^{48}$ Rosen himself has been associated with the 10,000 cuneiform tablets returned from Cornell University in 2013.49

Some of the private collectors are little known. For example, among the returns was a Roman marble head from the collection of Mr and Mrs Charles W. Newhall III. This had been purchased through the Montreal market. The head was identified from the Becchina photographic archive. Other private individuals listed as former owners from among the Getty material may have formed part of the complex acquisition plans of dealers outlined by Bruce McNall, owner of Summa Galleries. In his autobiography he explained how he worked with Jiri Frel to acquire objects that the Getty's board would otherwise be unwilling to acquire. ${ }^{50}$ It seems that objects were identified and private individuals would then be invited to acquire and donate them with tax benefits.

\section{Corporate Owners}

Some individuals may have acquired objects as an investment that could be realised in their future sale. This is reflected in the formation of the Athena Funds where objects were laid down and then sold at a major sale. Thus, for example, the Roman silver "Swiss army penknife" (now in the Fitzwilliam Museum) was sold through this fund even though its only previous collecting history was its viewing in a Soho safe. ${ }^{51}$

Classical sculptures are seen as appropriate backdrop to private houses and living spaces, but they have also been used by corporations. In 2011 two Roman statues, one representing Fortuna, were returned from Humana, a Healthcare company. ${ }^{52}$ One had been acquired from the Merrin Gallery in New York in 1984. The Fortuna had been stolen in Rome in October 1986.

\section{Dealers and galleries}

The last twenty years have been dominated by a series of high profile seizures from dealers in Switzerland. The journalistic investigation into the operation of the antiquities department at Sotheby's in London established the supply of classical objects from Italy via middlemen in Switzerland. ${ }^{53}$ Sotheby's subsequently took the decision to cease selling antiquities in London and transferred the activity to New York. It has also encouraged a more rigorous due diligence search for antiquities appearing in their sales that has led to a significant decrease in toxic lots.

The Sotheby's investigation led the Italian authorities to the warehouse facilities of Giacomo Medici in the Geneva Freeport. The raid revealed a significant number of objects (approximately 3800) as well as a major dossier of Polaroid photographs documenting the pieces that had been handled by the

\footnotetext{
48 Jucker 1991.

${ }^{49}$ Noted in Gill 2014c, 57.

50 McNall 2003.

51 Vassilika 1998, 128-29, no. 62.

52 Noted in Gill 2012b, 64.

53 Watson 1997.
} 
dealer. It is this dossier that helped to make positive identifications with objects in various international collections. ${ }^{54}$

Yet Medici was not the only dealer operating out of Switzerland. Raids in Basel recovered a significant number of objects from the premises associated with Gianfranco Becchina. Alongside them were photographs and other documentary evidence that has helped to identify other material. The objects associated with Italy, some 4400 items, were returned in three trucks in November 2008. These items were finally displayed to the public in a major press event at the Terme di Diocleziano del Museo Nazionale Romano in January 2015. This attracted major public attention not least because the haul was valued at over 50 million euros.

In 2009 Operation Phoenix returned 251 antiquities worth around 2.7 million euros from Phoenix Ancient Art based in Geneva. Many objects seem to have been derived from Etruria and southern Italy. The raid on this gallery was significant as it has also handled such high profile objects as the Ka-Nefer-Nefer Egyptian mummy mask acquired by the St Louis Art Museum, and the Leutwitz bronze Apollo acquired by the Cleveland Museum of Art. 55

In June 2010 Operation Andromeda contributed to the return of some 337 antiquities worth 15 million euros, to be returned to Italy. They had formed part of the stock of the Japanese dealer Noryioshi Horiuchi who was based in Switzerland. Horiuchi was associated with the supply of objects to the newly established Miho Museum in Japan, and was known to have business connections with Becchina.

Not all the raids have taken place in Switzerland. The British authorities seized some 27,000 objects worth US $\$ 250$ million from 29 warehouses across London. ${ }^{56}$ These were associated with the London-based dealer Robin Symes. ${ }^{57}$ In addition raids on Symes' villa on the Greek island of Schinoussa allowed the authorities to gain access to a third major archive of photographs and documents. The Italian authorities have requested the return of the seized objects from the UK Government but there has been no satisfactory resolution to date.

These major, high profile raids have provided a snap-shot of the workings of the antiquities dealer's network. The seizure of documentary evidence and photographs of items that had passed through these same dealers in previous years has allowed further identifications to be made. In November 2007, the Royal-Athena Galleries (RAG) in New York agreed to hand over 8 items. Three of the pieces had been stolen from Italian collections between 1970 and 1975, and two of these had resided in the Morven collection. In spite of this claim, RAG continued to handle material that could be identified from the photographic archives. In 2010 Tsirogiannis was able to identify 15 items on sale by RAG and that could be identified from the Medici, Becchina and related photographic archives. RAG has also been associated with the inadvertent handling of material stolen from the archaeological museum in Corinth in 1998. It should be noted that in June 2012 Dr Jerome Eisenberg, the proprietor of RAG, was awarded the

\footnotetext{
54 Watson and Todeschini 2006. See also Gill and Tsirogiannis 2016.

55 Bennett 2013; Gill 2013b; Gill 2014a.

56 Watson 2006, 94.

57 Tsirogiannis 2012.
} 
Order of the Star of Italy by the Italian authorities for his co-operation with the investigations into the illicit market.

Other Manhattan galleries have been linked to returned material. In 2011 a bronze Zeus was returned to Italy. It was recognised that this figure had been stolen from Muzeo Nazionale Romano in 1980. The statue had surfaced in North American exhibitions in 1982 and 1983 with the (clearly false) claim that it had formed part of a Swiss private collection in the 1960s. In 1984 the statue was identified as the property of Edward H. Merrin of New York (hence the name, the Merrin Zeus). By 1988 it formed part of the Fleischman collection and appeared in the exhibition, "The Gods Delight: The Human Figure in Classical Bronze". ${ }^{8}$ It was subsequently sold at Sotheby's New York in December 2004. The Zeus was returned to Italy with a marble female torso that had been stolen from the museum in Terracina in 1988. It had been spotted in a New York gallery by a member of the Italian Carabinieri who had been on holiday in New York.

A Roman wall painting from Boscoreale was seized from an unspecified Manhattan gallery in $2009 .{ }^{9}$ It had been stolen from the archaeological store at Pompeii around 1997. Five other fragments stolen from the same store at the same time had previously been returned to Italy. Another unnamed Manhattan gallery returned six antiquities to Italy in April 2017.

Several pieces have been returned from Christie's in New York. One of the most important seizures was associated with the June 2009 sale. Prior to the sale, a Corinthian krater was seized. This had first surfaced in an auction at Sotheby's in 1985. After the sale had taken place two further items were seized and subsequently returned: an Attic pelike attributed to the Aegisthus painter and an Apulian situla. Both these pieces had passed through Bruce McNall's Summa Galleries in Los Angeles, surfacing in 1977 and in the mid-1980s.

Christie's again do not seem to have strengthened their due diligence process and material identified from the seized photographic archives has continued to appear in their auctions. ${ }^{60}$ Interestingly Christie's have tended to reject the identifications and press ahead with the sale of the lots although this has sometimes meant that their value has been diminished or that lots have been left unsold. Three pieces were identified in the June 2010 sale, including a youth with a cockerel, the property of a Massachusetts private collector, that had surfaced at a Christie's auction in London in 1997, although the catalogues failed to note that it had originally surfaced at Sotheby's In London in July 1992. The Apulian rhyton that had surfaced through Sotheby's in New York in June 1994. A Canosan terracotta had surfaced in London in July 1984, and had passed into an English private collection. Concerns were raised in the press but Christie's continued with the sale. Paolo Ferri commented on the action suggesting that Christie's were acting unethically. Two of the pieces were sold, and one was unsold.

More recently, a Sardinian figure, owned by Michael Steinhardt, was offered at auction at Christie's. An outcry by politicians in Sardinia led to diplomatic approaches to the US authorities. The figure was withdrawn from the auction. Michael Steinhardt is not without interest as he is also a member of the board of Christie's.

\footnotetext{
58 Kozloff, et al. 1988.

59 Noted in Gill 2009a, 65.

60 Tsirogiannis 2013c.
} 
Bruce McNall has been discussed as the person behind some of the returned material such as the collection formed by the Hunt Brothers, or items acquired by the Getty. Another dealer who has been linked to the returns is Edoardo Almagià. His name was associated with Etruscan silver bracelets that were returned from the Cleveland Museum of Art; the items had been given with Courtney Keep in honour of the museum's curator Arielle Kozloff. Revelations in the June 2010 New York Times led to a further investigation into material acquired by Princeton. ${ }^{61}$ In December 2011 the museum claimed that six items had been transferred to the Italians. They included an Attic red-figured calyxkrater that had been attributed to Euphronios. However, one of the 'items' consisted of 157 terracotta architectural fragments from an Etruscan temple, and a further item consisted of five architectural fragments. Interestingly these Etruscan objects were linked to an architectural fragment already returned by Princeton that had been provided by the Aboutaam brothers. The revelation meant that Maxwell Anderson conducted an urgent review of any material in the Dallas Museum of Art that had been acquired from Alamagia, and after a posting on the AAMD Object Registry they were returned to Italy. ${ }^{62}$ Other museums have also been identified as acquiring objects from Alamagia and it is unclear the state of their internal enquiries into the objects.

The seizures have not all taken place in New York. In October 2010 a statue of Zeus stolen from the Norwegian Institute in Rome was returned from an unspecified London dealer. A Roman marble sarcophagus stolen from the Chiesa della Modonna della Libera di Aquino in 1991 was recovered in London as part of Operation Giovenale. In 2008 the sale of the antiquities collection formed by the Australian dealer Graham Geddes at Bonham's in London was disrupted when the Italian authorities asked for a number of lots to be withdrawn including the Athenian krater that had featured on the front of the auctionhouse's magazine that was advertising the sale. ${ }^{63}$ In the end 10 lots were withdrawn from the sale, of which seven had surfaced at Sotheby's in London between 1984 and 1989. Geddes' name had already been associated with a Lucanian nestoris returned from Boston, and his name appeared against a Lucanian krater that was linked to Medici.

\section{Common pathways}

One of the common routes for this archaeological material to enter the market is by Switzerland. Objects have been identified from the Medici and Becchina photographic archives suggesting that they formed the stock in Italy. Several pieces in Boston were sold by the restorer Fritz Bürki. They include the statue of Sabina. The Fleischman collection included a Pontic amphora and an Apulian bell-krater that had been handled by Bürki. At least one object in Madrid appears in a photograph of a group of objects that appear to have been in Bürki's bathroom studio. It was reported that some of the Cleveland material was derived from Bürki. It appears that some 350 pieces handled by Bürki appear in a series of photographs that are in the possession of the Italian police.

\footnotetext{
61 Gill 2012b.

62 Gill 2013a.

63 Gill 2009d, 83-84.
} 
Peter Watson's investigation into the paperwork relating to the department of antiquities at Sotheby's demonstrated a link between Medici, his Swiss agents and Sotheby's. ${ }^{64}$ Consignment lists to Sotheby's contain material that can be identified. So far at least seven objects that have been returned to Italy could be demonstrated to have passed through Sotheby's in London. This "toxic" route also caused problems for the sale of the Geddes collection at Bonham's in London when several pieces had to be withdrawn.

One of the areas that has not yet been investigated is whether or not Medici made consignments to Sotheby's in New York. However, it is clear that a handful of pieces now returned to Italy did enter the market via that route raising the spectre that there could be further disruptions to unsettle the market, museums and collectors.

The Attic krater returned from Minneapolis had been recorded as forming part of a Swiss private collection. ${ }^{65}$ However, it appears in a Polaroid within the Medici dossier. It appears that the krater had been passed from Medici to Symes who had sold the piece to Minneapolis. This relationship means that the collecting histories of material handled by Symes need to be investigated. ${ }^{66} \mathrm{His}$ connection with objects has caused disruption at a number of sales including Bonham's in London and Christie's in the Rockefeller Centre.

Bonhams has been linked to other items that have been withdrawn from sales or left unsold at auction. Apart from the Geddes sale, these items included a Roman marble statue of a youth that had surfaced through Sotheby's in London but was identified from the Medici dossier. ${ }^{67}$

In terms of fragments there is concern that complete pots may have been deliberately broken and their fragments passed to individual collectors or dealers who then sold or donated the objects so that they could be reunited in the target museum. An area that has not been explored is the attribution of Athenian and South Italian pottery to named largely anonymous pot-painters. It is unclear when scholars were shown the pots or fragments for attribution, or if they were unaware that they were commenting on recently surfaced material. It would be of some concern if any of them received payments in kind.

\section{Themes of material}

What sort of archaeological material from Italy was being acquired by North American museums and private collectors? Pottery dominates the returns. Many of the items are complete pieces that are likely to have been removed from graves where they had been protected (with their funerary assemblages) for some 2500 years. The pottery falls into two main groups: Athenian and South Italian.

The Athenian pottery is dominated by the Sarpedon krater returned by the Metropolitan Museum of Art. The association with Euphronios leads to further companion pieces. ${ }^{68}$ One is the Kyknos krater returned by Shelby White, and another is the fragmentary (consisting of four pieces) calyx-krater in Princeton.

\footnotetext{
64 Watson 1997.

65 Gill 2011.

66 Tsirogiannis 2012.

67 Gill and Tsirogiannis 2011. For further discussion: Gill 2014b.

68 Exhibition catalogue 1990.
} 
Linked to these pieces is the cup that had formed part of the Hunt collection and had passed into the holdings of Medici.

Three pots attributed to the Berlin painter have been returned. Among them is a fragmentary krater that had been acquired by the Getty from 1977 to $1990 .{ }^{69}$ Among the donors or vendors of the fragments were Dietrich von Bothmer, Herbert Lucas, Vasek Polak, Frederick H. Schultz Jr and Robin Symes. A further set of 35 fragments were loaned in 1989 reportedly from Giacomo Medici. An amphora attributed to the same painter was returned from New York's Metropolitan Museum of Art. ${ }^{70}$ Robert Guy supplied some 15 additional fragments. The amphora was identified from the Medici Dossier when it was in 'the early stages of restoration'. Finally a hydria was returned from Boston. ${ }^{71}$ This had been acquired from Fritz Bürki.

South Italian pottery is well represented among the returns. ${ }^{72}$ Apulian pottery forms a major component. One of the best represented painters is the Darius painter: a volute-krater from Cleveland, an amphora from Boston, a loutrophoros from Princeton, a pelike from the Getty, and a dinos from New York. A pot attributed to the Darius painter was returned as part of Operation Andromeda. The Madrid collection also contains a work attributed to the Darius painter. Works attributed to the Darius painter also feature prominently in a supposed tomb-group acquired by Berlin. ${ }^{73}$

Etruscan material features regularly in the returns. The largest group consists of a series of architectural fragments from a temple that was returned by Princeton. Other terracotta architectural fragments include the satyr and Maenad from the Getty, or the two separate groups of fragments from the Getty. Princeton's return included an Etruscan tufa lion. Other returned pieces include Etruscan bronzes and sculptures.

Roman material is less visible in the returns. One of the reasons may be that it is harder to associate material culture with a specific modern nation state as such items can be found across the lands formally occupied by the Roman Empire. Among the sculpture is the Roman portrait of Sabina, the marble Fortuna, and the series of sculptures returned from the Getty that may be associated with a villa complex in southern Italy. Three fragments of Roman wall-painting from the same composition were returned from the Getty (ex Fleischman) and the Shelby White and Leon Levy collection. Other wall-painting fragments were returned as part of Operation Andromeda.

\section{MOUs and Reciprocal Loans}

One of the ways that the US and Italian authorities have worked together to try and reduce the amount of looting of archaeological sites in Italy has been through a bilateral agreement first made in 2001 and renewed in $2010 .{ }^{74}$ This has sought to identify cultural property that is specifically linked to Italy that would encourage a more thorough investigation when imported to the US.

\footnotetext{
${ }^{69}$ Gill 2012a, 79.

70 Gill 2012a, 81.

${ }^{71}$ Gill and Chippindale 2006, 325, no. 6.

72 For some of the issues: Gill and Chippindale 2008.

73 Gill 2009d, 80-82, fig. 2.

74 Gill 2010a.
} 
Controversially, the agreement has been expanded to include certain categories of ancient coins. ${ }^{75}$ This has been opposed rigorously by lobbying groups representing numismatic dealers not just in north America but also in Europe who were concerned that part of their potential market would be restricted.

Part of the bilateral agreement encourages the Italian authorities to protect archaeological sites and their heritage. The level of looting can be measured in part by the apparent decrease in seizures by the Carabinieri. Concerns have been raised about the deterioration of some complex archaeological sites such as Pompeii as evidence that the Italian authorities are not concerned about their cultural heritage. However, all national governments are facing fiscal pressures during the present economic crisis, and the preservation, protection and conservation of extensive long-excavated remains that are open to the elements is an issue that remains a long-term problem. It is also a reminder that the excavation of archaeological remains needs to include a long-term plan for the display, interpretation and protection of remains that are deemed worthy of public display.

The bilateral agreement has also made provision for the loan of archaeological remains from the major holdings of museums in Italy. These loans have included the bronze chimaera in Florence that was placed on loan to the Getty, and Attic pottery that was loaned to the Metropolitan Museum of Art. In addition, the Italians co-curated a major loan exhibition on Sicily that was displayed in the Getty and Cleveland Museum of Art. ${ }^{76}$ University and civic museums such as Dallas, Fordham and Princeton have been allowed to retain some of the objects they had acquired although the legal title has been transferred to the Italian authorities. This reflects the Italian authorities' willingness to avoid unnecessary disruption to public displays while asserting their legal rights over looted cultural property.

\section{Conclusion}

The returns from North American museums, private collectors, and galleries have been high damaging for the reputations of institutions, businesses and private individuals. Some of the reputational damage could have been avoided by the application of more developed ethical standards over acquisitions and the handling of recently surfaced material.

The debate about returning antiquities has focussed somewhat on why North American museums should be forced to return material to Italy when its museums and archaeological stores are already full of material that cannot be placed on public display. Indeed, there has been a public suggestion by Anna Somers-Cocks that the Italian authorities should sell off part of their rich collections to create an income to protect archaeological remains. ${ }^{77}$ One of the key issues is that looting of archaeological sites has material consequences. Cemeteries are disturbed, grave-groups are broken up, associations lost, and even general information about general find-spots are left unrecorded. The sum total is that very specific information is lost and can never be recovered even by informed stylistic studies of the material. Thus, the uncontrolled acquisition of

75 Elkins 2008; Elkins 2009; Elkins 2010.

${ }^{76}$ Lyons, et al. 2013.

77 Somers Cocks 2015. 
newly surfaced archaeological material by public museums and private collectors in North America (and elsewhere) was unsustainable for the archaeological record. The negative publicity for museums, private individuals and galleries has discouraged the trade and thereby decreased the demand for material with linked decrease in looting.

Collectors may be seen to be exempt from these concerns. However, there are issues about what happens to the collection when dealers die or no longer wish to own it. Curators in North America will be reluctant to acquire recently surfaced material from collectors unless there is authenticated documentation demonstrating that the objects had not been looted. After all, would a museum wish to acquire material from a private collection only to have to go through a damaging return process if the objects were identified from a known or some other photographic archive that will be revealed in the future? But if the objects are sold through a gallery or auction-house, the same concerns are there. It is clear from the sale of the Steinhardt Sardinian figure that once an object is identified from one of the photographic archives an object has either to be withdrawn from sale or it runs the risk of being left unsold. An object that may have been acquired as an investment could end up as a worthless item: worthless in terms of monetary value, and worthless in scientific value as it has been stripped of its archaeological information.

The spate of returns as a result of the recovery of the Becchina, Medici, and Schinoussa documentary and photographic archives have been the result not of complex legal cases, but through negotiated returns. Museums and the Italian authorities have been saved the complexity of legal cases that could have cost more than the value of the objects that the Italians were seeking to have returned. And for museums they have avoided having to release acquisition policies and decision making that could have led to significant embarrassment for directors, trustees, and curatorial staff; and there were implications where staff have moved to other institutions.

The returns have influenced institutional changes in North American museums. ${ }^{78}$ The newly formulated guidelines for acquiring antiquities and ancient art that have been issued by the Association of Art Museum Directors reflect a desire to move in the direction of responsible collecting. Indeed, the creation of the AAMD Object Registry shows a desire for museums to adopt a level of transparency. The system is not, of course, perfect. The unwillingness of the Metropolitan Museum of Art to place online even a significant proportion of the Bothmer collection of pottery sherds could be interpreted as protecting his memory. ${ }^{79}$ Given that part of the collection has already had to be returned to Italy, there are genuine concerns that the pot sherds include associations that have yet to be made, perhaps with fragmentary pots that have already been returned to Italy. But it takes time to photograph and digitise the records so we look forward to this task to be completed to allow public scrutiny.

More disturbing is the provocative acquisition of apparently newly surfaced antiquities by major museums that could be seen as a challenge to the AAMD guidelines. For example, the Cleveland Museum of Art acquired the portrait statue of Drusus Minor that it claimed had been acquired form an old Algerian

\footnotetext{
78 Gill 2009b.

79 Tsirogiannis and Gill 2014.
} 
collection. The secure collecting history can only be traced back to 2004, whereas the oral history, unsupported by documented and authenticated paperwork, attempts to place it in the late $19^{\text {th }}$ century. ${ }^{80}$ The return of the portrait to Italy in 2017 is a reminder that the museum had been unwise to pursue the acquisition. In addition, the acquisition of the Leutwitz Apollo by the same museum (and from the same Swiss dealer) has raised concerns about the veracity of part of the collecting history. ${ }^{81}$ The alleged emergence of the fragmentary statue in a private house in eastern Germany has raised serious questions about the authenticity of the account.

This discussion has focussed on material derived from Italy but it is only the tip of an iceberg. Material such as the gold wreath, a marble kore, ${ }^{82}$ an inscription from Thorikos, and a funerary stele have been returned from the Getty, and Shelby White has returned the upper part of a funerary stele that fits the lower part excavated in a rural cemetery in southern Attica. ${ }^{83}$ Boston's Museum of Fine Arts has returned the upper part of the Weary Herakles that fitted the lower part of the statue that had been excavated in Pamphylia in southern Turkey. Dallas has voluntarily returned a Late Roman mosaic to Turkey. Shelby White has agreed to return a set of Roman bronze statues from Icklingham, Suffolk, to the United Kingdom after her death. ${ }^{84}$

The returns have demonstrated the power of media, and increasingly social media, to influence public opinion and to encourage museum teams to return improperly acquired objects. ${ }^{85}$ It is unlikely that the Italian authorities would have achieved the same result if they had approached each museum, collector and gallery through a court-case. The costs are also likely to have been prohibitive.

In the long-term what is needed is a more rigorous due diligence process put in place by the market, and a more cautious and ethically responsible approach by museums and other acquirers of such archaeological material.

\footnotetext{
80 Gill 2013b, 72.

81 Gill 2013b.

${ }^{82}$ Athens, National Archaeological Museum. Godart and De Caro 2007, 234-35, no. 68.

83 Gill 2009d, 88-91, fig. 4.

${ }^{84}$ Browning 1995. See also Reynolds 1990.

85 Gill 2014d.
} 


\begin{tabular}{|c|c|c|c|c|c|}
\hline Source & $\begin{array}{l}\text { Greek } \\
\text { pottery }\end{array}$ & $\begin{array}{l}\text { South } \\
\text { Italian } \\
\text { pottery }\end{array}$ & $\begin{array}{l}\text { Etruscan } \\
\text { material }\end{array}$ & Sculpture & Other \\
\hline $\begin{array}{l}\text { Boston } \\
\text { Museum of } \\
\text { Fine Arts }\end{array}$ & 6 & 5 & & 2 & \\
\hline $\begin{array}{l}\text { Cleveland } \\
\text { Museum of } \\
\text { Art }\end{array}$ & 2 & 8 & 3 & 1 & 2 \\
\hline $\begin{array}{l}\text { Dallas } \\
\text { Museum of } \\
\text { Art }\end{array}$ & & 3 & 3 & & \\
\hline $\begin{array}{l}\text { Fordham } \\
\text { University Art } \\
\text { Museum }\end{array}$ & & & 1 & & \\
\hline $\begin{array}{l}\text { The J. Paul } \\
\text { Getty Museum }\end{array}$ & 20 & 9 & 5 & 8 & 8 \\
\hline $\begin{array}{l}\text { Minneapolis } \\
\text { Institute of } \\
\text { Art }\end{array}$ & 1 & & & & \\
\hline $\begin{array}{l}\text { New York, } \\
\text { Metropolitan } \\
\text { Museum of } \\
\text { Art }\end{array}$ & 4 & 2 & & & 15 \\
\hline $\begin{array}{l}\text { Princeton } \\
\text { University Art } \\
\text { Museum }\end{array}$ & 4 & 2 & 166 & 1 & 2 \\
\hline Toledo & & & 1 & & \\
\hline $\begin{array}{l}\text { University of } \\
\text { Virginia Art } \\
\text { Museum in } \\
\text { Charlottesville }\end{array}$ & & & & 2 & \\
\hline $\begin{array}{l}\text { Royal Athena } \\
\text { Galleries }\end{array}$ & 3 & & 4 & 1 & \\
\hline Shelby White & 5 & & 2 & & 3 \\
\hline $\begin{array}{l}\text { Dietrich von } \\
\text { Bothmer }\end{array}$ & 41 & & & & \\
\hline Christie's & 3 & 2 & & 1 & \\
\hline Other & 3 & 2 & 1 & & 3 \\
\hline TOTAL & 92 & 33 & 186 & 16 & 38 \\
\hline
\end{tabular}

Table 1. Overview of types of material returned to Italy from North American sources. This includes material placed on loan with museum. 


\section{References}

Anderson, M. L. 2017. Antiquities: what everyone needs to know. Oxford: Oxford University Press.

Anderson, M. L., and L. Nista. 1988. Roman portraits in context: imperial and private likenesses from the Museo Nazionale Romano. Rome: De Luca Edizioni d'Arte.

-. Editors. 1989. Radiance in stone: sculptures in colored marble from the Museo Nazionale Romano. Rome: De Luca Edizioni d'Arte.

Bennett, M. 2013. Praxiteles: the Cleveland Apollo. Cleveland Masterwork Series, vol. 2. Cleveland: The Cleveland Museum of Art.

Bothmer, D. v. 1987. Greek vase painting. New York: The Metropolitan Museum of Art.

-. Editor. 1990. Glories of the past: ancient art from the Shelby White and Leon Levy collection. New York: Metropolitan Museum of Art.

Browning, J. 1995. "A layman's attempts to precipitate change in domestic and international 'heritage' laws." In Antiquities trade or betrayed: legal, ethical and conservation issues, edited by K. W. Tubb: 145-49. London: Archetype.

Butcher, K., and D. W. J. Gill. 1990. "Mischievous pastime or historical science?" Antiquity 64: 946-50.

Cabrera Bonet, P. Editor. 2003. La colección Várez Fisa en el Museo Arqueológico Nacional. Madrid: Ministerio de Educación, cultura y Deporte.

Cavaliere, B., and J. Udell. Editors. 2012. Ancient Mediterranean art: The William D. and Jane Walsh collection at Fordham University. New York: Fordham University Press.

Chi, J., and J. Gaunt. 2005. Greek bronze vessels from the collection of Shelby White \& Leon Levy. Atlanta: Michael C. Carlos Museum, Emory University.

Chippindale, C., and D. W. J. Gill. 2000. "Material consequences of contemporary classical collecting." American Journal of Archaeology 104: 463-511.

Christiansen, J. 2008. "I mediernes søgelys." Ny Carlsbergsfondets Årsskrift: 13845.

Christiansen, J., N. A. Winter, and P. S. Lulof. 2010. Architectural terracottas and painted wall plaques, pinakes: c. 625-200 BC. Copenhagen: Ny Carlsberg Glyptotek.

Cuno, J. 2008. Who owns antiquity? Museums and the battle over our ancient heritage. Princeton: Princeton University Press.

de Montebello, P. 2007. "Whose culture is it? Museums and the collection of antiquities." The Berlin Journal 15: 33-37.

—. 2009. ""And what do you propose should be done with those objects?"." In Whose culture? The promise of museums and the debate over antiquities, edited by J. Cuno: 55-70. Princeton: Princeton University Press.

Elkins, N. T. 2008. "A survey of the material and intellectual consequences of trading in undocumented ancient coins: a case study on the North American trade." Frankfurter elektronische Rundschau zur Altertumskunde 7: 1-13.

—. 2009. "Treasure hunting 101 in America's classrooms." Journal of Field Archaeology 34: 481-89.

-. 2010. "Ancient coins and Washington politics." Journal of Art Crime 2. 
Exhibition catalogue. 1990. Euphronios, peintre à Athènes au VIe siècle avant J.-C. : Musée du Louvre, Paris, 18 septembre-31 décembre 1990. Paris: Editions de la Réunion des musées nationaux.

-.1994. A passion for antiquities: ancient art from the collection of Barbara and Lawrence Fleischman. Malibu, Calif.: J. Paul Getty Museum in association with the Cleveland Museum of Art.

Felch, J., and R. Frammolino. 2011. Chasing Aphrodite: the hunt for looted antiquities at the world's richest museum. Boston: Houghton Mifflin Harcourt.

Gill, D. W. J. 1997. "Sotheby's, sleaze and subterfuge: inside the antiquities trade." Antiquity 71: 468-71.

-. 2007. "Review of E. Robson, L. Treadwell, and L. Gosden (eds.), Who owns objects? The ethics and politics of collecting cultural artefacts (Oxford: Oxbow, 2006), and N. Brodie, M.M. Kersel, C. Luke, and K.W. Tubb (eds.), Archaeology, cultural heritage, and the antiquities trade (Gainesville: University Press of Florida, 2006)." Journal of Field Archaeology 32: 1030106.

—. 2009a. "Context matters: looting in the Balkans." Journal of Art Crime 1: 6366.

—. 2009b. "Context matters: museums and the looted world." Journal of Art Crime 1: 43-46.

-. 2009c. "Homecomings: learning from the return of antiquities to Italy." In Art and Crime: exploring the dark side of the art world, edited by N. Charney: 13-25. Santa Barbara: Praeger.

-. 2009d. "Looting matters for classical antiquities: contemporary issues in archaeological ethics." Present Pasts 1: 77-104.

—. 2010a. "Context Matters. Italy and the US: reviewing cultural property agreements." Journal of Art Crime 3: 81-85.

- 2010b. "The returns to Italy from North America: an overview." Journal of Art Crime 3: 105-09.

-. 2011. "Context matters: the unresolved case of the Minneapolis krater." Journal of Art Crime 5: 57-61.

- 2012a. "Context matters: Fragmented pots, attributions and the role of the academic." Journal of Art Crime 8: 79-84.

—. 2012b. "Context matters: Princeton and recently surfaced antiquities." Journal of Art Crime 7: 59-66.

-. 2012c. "The material and intellectual consequences of acquiring the Sarpedon krater." In All the King's Horses: essays on the impact of looting and the illicit antiquities trade on our knowledge of the past, edited by P. K. Lazrus and A. W. Barker: 25-42. Washington DC: Society for American Archaeology.

—. 2013a. "Context matters: Dallas Museum of Art takes the initiative." Journal of Art Crime 9: 79-84.

—. 2013b. "Context matters: The Cleveland Apollo goes public." Journal of Art Crime 10: 69-75.

-. 2014a. "The case of the Ka Nefer Nefer mummy mask." Journal of Art Crime 12: $13-25$.

-. 2014b. "Context matters: Learning from the Herm: the need for more rigorous due diligence searches." Journal of Art Crime 12: 57-62. 
—. 2014c. "Context matters: the so-called Crosby Garrett helmet." Journal of Art Crime 11: 53-59.

—. 2014d. "Looting Matters: blogging in a research context." In Blogging archaeology, edited by D. Rocks-Macqueen and C. Webster: 44-59, 246-67: Landward Research Ltd.

—. 2016a. "Context matters: the returns from the Ny Carlsberg Glyptotek, Copenhagen." Journal of Art Crime 16: 81-87.

—. 2016b. "Thinking about collecting histories: a response to Marlowe." International Journal of Cultural Property 23: 237-44.

—. 2017. "Context matters: Drusus Minor and Tiberius." Journal of Art Crime 17: 89-96.

Gill, D. W. J., and C. Chippindale. 2006. "From Boston to Rome: reflections on returning antiquities." International Journal of Cultural Property 13: 31131.

-. 2007. "From Malibu to Rome: further developments on the return of antiquities." International Journal of Cultural Property 14: 205-40.

—. 2008. "South Italian pottery in the Museum of Fine Arts, Boston acquired since 1983." Journal of Field Archaeology 33: 462-72.

Gill, D. W. J., and C. Tsirogiannis. 2011. "Polaroids from the Medici Dossier: continued sightings on the market." Journal of Art Crime 5: 27-33.

-. 2016. "Polaroids from the Medici dossier: continued sightings on the market." In Art crime: terrorists, tomb raiders, forgers and thieves, edited by $\mathrm{N}$. Charney: 229-39. New York: Palgrave Macmillan.

Godart, L., and S. De Caro. Editors. 2007. Nostoi: Capolavori ritrovati. Roma, Palazzo del Quirinale, Galleria di Alessandro VII, 21 dicembre 2007 - 2 marzo 2008. Rome: Segretariato Generale della Presidenza della Repubblica.

Isman, F. 2010. "Looted from Italy and now in a major Spanish museum? Madrid's National Archaeological Museum may have bought trafficked items." The Art Newspaper July 13, 2010.

Jucker, I. 1991. Italy of the Etruscans: archaeological finds from the first millennium BCE. Jerusalem: The Israel Museum.

Kozloff, A. P., D. G. Mitten, and S. Fabing. 1988. The Gods delight: the human figure in classical bronze. Cleveland, Ohio ; Bloomington, Ind: Published by the Cleveland Museum of Art in cooperation with Indiana University Press : Distributed by Indiana University Press.

Lyons, C. L., M. Bennett, C. Marconi, and A. Sofroniew. Editors. 2013. Sicily: art and invention between Greece and Rome. Los Angeles: The J. Paul Getty Museum.

Mackenzie, S. 2005. Going, going, gone: regulating the market in illicit antiquities. Leicester: Institute of Art and Law.

Marlowe, E. 2016. "What we talk about when we talk about provenance: a response to Chippindale and Gill." International Journal of Cultural Property 23: 217-36.

McNall, B. 2003. Fun while it lasted. New York: Hyperion.

Miho Museum. 1997. Miho Museum: The South Wing: The Miho Museum.

Ortiz, G. 1994. In pursuit of the absolute: art of the ancient world from the George Ortiz collection. Berne: Benteli-Werd. 
Özgen, I., and J. Öztürk. 1996. The Lydian treasure: heritage recovered. Istanbul: Republic of Turkey, Ministry of Culture General Directorate of Monuments and Museums.

Padgett, J. M. 1983-86 [1991]. "An Attic red-figure volute-krater." Minneapolis Institute of Arts Bulletin 66: 66-77.

Paul, A. J. 1997. "Fragments of antiquity: drawing upon Greek vases." Harvard University Art Museums Bulletin 5: 1-87.

Reynolds, N. 1990. "The Icklingham bronzes." Minerva 1: 10-11.

Sgubini, A. M. M. 1999. Euphronios epoiesen: un dono d'eccezione ad Ercole Cerite. Rome: L'Erma di Bretschneider.

Silver, V. 2009. The lost chalice: the epic hunt for a priceless masterpiece. New York: William Morrow.

Somers Cocks, A. 2015. "Why Italy should sell the 5,000 antiquities recovered by the police." The Art Newspaper March 25, 2015.

Tompkins, J. F. Editor. 1983. Wealth of the ancient world: the Nelson Bunker Hunt and William Herbert Hunt collections. Fort Worth (TX): Kimbell Art Museum.

Tsirogiannis, C. 2012. Unravelling the hidden market of illicit antiquities: The Robin Symes - Christos Michaelides network and its international implications. PhD Dissertation, Cambridge University.

—. 2013a. "A marble statue of a boy at the Virginia Museum of Fine Arts." Journal of Art Crime 9: 55-60.

-. 2013b. "Nekyia. From Apulia to Virginia: an Apulian Gnathia askos at the Virginia Museum of Fine Arts." Journal of Art Crime 10: 81-86.

-. 2013c. "Something is confidential in the state of Christie's." Journal of Art Crime 9: 3-19.

—. 2014. "Nekyia: a South Italian bell-krater by Python in the Metropolitan Museum of Art." Journal of Art Crime 11: 63-68.

-. 2017. "Nekyia: Museum ethics and the Toledo Museum of Art." Journal of Art Crime 17: 77-87.

Tsirogiannis, C., and D. W. J. Gill. 2014. "'A fracture in time': a cup attributed to the Euaion painter from the Bothmer collection." International Journal of Cultural Property 21: 465-80.

Vassilika, E. 1998. Greek and Roman Art. Fitzwilliam Museum Handbook. Cambridge: Cambridge University Press.

Vickers, M., and D. W. J. Gill. 1994. Artful crafts: ancient Greek silverware and pottery. Oxford: Clarendon Press.

Watson, P. 1997. Sotheby's, the inside story. London: Bloomsbury.

—. 2006. "Convicted dealers: what we can learn." In Archaeology, cultural heritage, and the antiquities trade, edited by N. Brodie, M. M. Kersel, C. Luke, and K. W. Tubb: 93-97. Gainesville: University Press of Florida.

Watson, P., and C. Todeschini. 2006. The Medici conspiracy: the illicit journey of looted antiquities from Italy's tomb raiders to the world's great museums. New York: Public Affairs.

Wescoat, B. D., and M. L. Anderson. 1989. Syracuse, the fairest Greek city: ancient art from the Museo archeologico regionale 'Paolo Orsi'. Roma, Italia: De Luca edizioni d'arte. 